\title{
ANALISIS PREFERENSI MASYARAKAT PESANTREN TERHADAP BANK SYARIAH (Studi Kasus Kecamatan Tampan)
}

\author{
SEHANI, SE, MM \\ Fakultas Ekonomi dan Ilmu Sosial UIN Sultan Syarif Kasim Riau \\ E-mail : shany.bongky@gmail.com
}

\begin{abstract}
Abstrak
Tujuan dari penelitian ini adalah untuk mengetahui dan menganalisis preferensi masyarakat pesantren di Kecamatan Tampan terhadap bank syariah dan untuk mengetahui faktor-faktor yang mempengaruhi preferensi masyarakat pesantren di Kecamatan Tampan terhadap bank syariah. Populasi adalah masyarakat pesantren yang menjadi nasabah bank syariah di Kecamatan Tampan dengan jumlah sampel penelitian sebanyak 100 orang responden. Dalam pengambilan sampel penulis menggunakan metode accidental Sampling. Variable bebas adalah manfaat yang diperoleh $\left(X_{1}\right)$, aktualisasi diri $\left(X_{2}\right)$, penghargaan dari lingkungan $\left(X_{3}\right)$. Sedangkan variable terikatnya adalah preferensi masyarakat pesantren. Teknik analisis data yang digunakan dalam penelitian ini adalah analisis regresi berganda. Hasil penelitian menunjukkan bahwa seluruh variabel bebas yang diteliti yaitu manfaat yang diperoleh $\left(X_{1}\right)$, aktualisasi diri $\left(X_{2}\right)$, penghargaan dari lingkungan $\left(X_{3}\right)$ secara bersama-sama mempunyai pengaruh yang signifikan terhadap preferensi masyarakat pesantren. Secara parsial terbukti bahwa variabel manfaat yang diperoleh $\left(X_{1}\right)$ mempunyai pengaruh yang dominan terhadap preferensi masyarakat pesantren.
\end{abstract}

Kata Kunci: preferensi masyarakat pesantren, bank syariah.

\section{PENDAHULUAN}

Dewasa ini bank syariah di Indonesia telah mengalami perkembangan yang pesat dan dapat dikatakan cukup signifikan. Perhatian yang cukup besar dari pemerintah pun diberikan melalui peran Bank Indonesia dalam memantau dan mengawasi jalannya perkembangan bank syariah tersebut. Preferensi masyarakat terhadap bank syariah ditunjukkan dengan respon yang sangat variatif. Pertimbangan nasabah dalam memilih bank syariah menjadi salah satu hal yang perlu untuk diskusikan guna mengetahui apa sesungguhnya yang menjadi keinginan dan mengetahui sejauhmana minat masyarakat terhadap bank syariah di Indonesia ini.

Bank sebagai lembaga kepercayaan yang merupakan bagian dari sistem moneter merupakan sarana untuk pembentukan dana alokasi tabungan masyarakat. Maka peranan kebijakan moneter dalam suatu perekonomian sangat penting untuk menciptakan dan memelihara suatu tingkat kestabilan ekonomi. 
Sesuai dengan pengertian bank menurut UU-RI No. 10/1998 tentang Perbankan "Bank adalah badan usaha yang menghimpun dana dari masyarakat dalam bentuk simpanan dan menyalurkannya kepada masyarakat dalam bentuk kredit dan/atau bentuk-bentuk lainnya dalam rangka meningkatkan taraf hidup rakyat banyak". Dan pasal 29 menyebutkan bahwa “ Mengingat bank terutama bekerja dengan dana dari masyarakat yang disimpan pada bank atas dasar kepercayaan, setiap bank perlu terus menjaga kesehatannya dan memelihara kepercayaan masyarakat kepadanya".

$\begin{array}{ccc}\text { Karakteristik bank } & \text { syariah } \\ \text { yang sangat unik karena }\end{array}$ berlandaskan syariat Islam yang mengharamkan riba dalam setiap transaksi keuangan yang berupa penyimpanan maupun penyaluran dana yang tidak dikenakan bunga (interest free banking), perbankan syariah juga berfungsi sebagai lembaga perantara keuangan yang melakukan transaksi-transaksi yang sama seperti bank konvesional. Keunikan Karakteristik ini juga mengindikasikan berbagai hal termasuk minat (preferensi) masyarakat yang berbeda terhadap bank syariah, perilaku masyarakat yang berbeda dalam menabung dan riba yang diharamkan dalam syariat Islam sebagi pemicu perbedaan karakteristik antara bank syariah dan bank konvensional.

Produk pembiayaan Bank Syariah mempunyai spesifikasi khas, yaitu tidak didasarkan pada bunga tetapi menggunakan pola bagi hasil. Dari sekian banyak produk pembiayaan bank syariah terdapat tiga yang sangat dominan yaitu mudharabah, musyarakah, dan murabahah. Mudharabah merupakan perjanjian bagi hasil antara pemilik modal (uang atau barang) dengan pengusaha (enterpreneur) yang memiliki keahlian atau pengalaman dalam pengelolaan sebuah proyek. Di sini pemodal tidak diperbolehkan pengelola usaha namun sekedar pengusulan dan pengawasan. Bila usaha ini mengalami kerugian akan sepenuhnya ditanggung pemilik modal kecuali bila ada penyelewengan dari pengusaha.

$$
\text { Musyarakah merupakan }
$$
perjanjian kerjasama antara dua pihak atau lebih pemilik modal (uang atau barang) untuk membiayai suatu usaha. Keuntungan dibagi sesuai perjanjian namun kerugian yang terjadi dibagi berdasarkan modal masing-masing. Murabahah merupakan persetujuan jual beli suatu barang dengan harga sebesar harga pokok ditambah keuntungan yang disepakati bersama, di sini disertakan cara pembayarannya. Potensi pasar produk perbankan Syariah di Kota Pekanbaru cukup besar, mengingat mayoritas masyarakat Kota Pekanbaru adalah muslim dan ini merupakan nasabah potensial bagi Bank Syariah. Kemudian ditambah lagi dengan semakin baiknya perkembangan pesantren-pesantren di Kota Pekanbaru dimana ini merupakan segmen potensial juga bagi Bank Syariah yang ada di Kota Pekanbaru.

Sebagai salah satu kegiatan ekonomi, keberadaan lembaga keuangan, khususnya perbankan di Kota Pekanbaru dirasakan sangat strategis khususnya untuk 
mendukung ketersediaan modal, baik yang bersifat modal investasi, modal kerja maupun konsumsi.

\begin{tabular}{rrr}
\multicolumn{2}{c}{ Perkembangan perbankan } \\
syariah di Kota Pekanbaru
\end{tabular} menunjukkan pertumbuhan yang menggembirakan. Hal ini terlihat dari penyebaran jumlah kantor baik sebagai kantor cabang utama, kantor cabang pembantu maupun kantor kas yang hanya melayani penarikan dan penyetoran uang nasabah. Berdasarkan laporan Bank Indonesia, kinerja perbankan syariah menunjukkan perkembangan yang lebih baik. Aset perbankan syariah di Provinsi Riau pada triwulan IV-2011 mencapai Rp3,25 triliun atau meningkat sebesar $8,11 \%$. Peningkatan aset tersebut utamanya didorong oleh meningkatnya DPK yaitu dari $\mathrm{Rp} 2,15$ triliun menjadi Rp2,34 triliun atau naik 8,73\%. Pertumbuhan DPK tersebut jauh diatas pertumbuhan industri perbankan di Riau yang hanya sebesar 21,28\%. Dengan demikian, pangsa aset Perbankan syariah terhadap total perbankan di Provinsi Riau saat ini telah mencapai 5,37\%.

Berdasarkan uraian diatas, maka penulis akan meneliti preferensi masyarakat pesantren terhadap bank syariah khususnya di Kecamatan Tampan. Dalam rangka menghadapi persaingan dan memperluas pasar, maka perilaku konsumen mengenai sikap seseorang memutuskan untuk menjadi nasabah pada Bank Syariah sangat penting untuk diketahui dan dipahami.

Adapun permasalahan yang dikemukakan dalam penelitian ini adalah:
1. Bagaimana preferensi masyarakat pesantren di Kecamatan Tampan terhadap bank syariah?

2. Faktor-faktor apakah yang mempengaruhi preferensi masyarakat pesantren di Kecamatan Tampan terhadap bank syariah?

Tujuan penelitian ini adalah:

1. Untuk mengetahui dan menganalisis preferensi masyarakat pesantren di Kecamatan Tampan terhadap bank syariah.

2. Untuk mengetahui faktor-faktor yang mempengaruhi preferensi masyarakat pesantren di Kecamatan Tampan terhadap bank syariah.

Teori-teori yang mendukung penelitian ini dijelaskan dalam penjabaran dibawah ini:

1. Teori Preferensi

Preferensi adalah evaluasi sesorang mengenai dua atau lebih objek. Preferensi melibatkan perbandingan diantara objek. Preferensi merupakan bagian dasar konsumen dalam keseluruhan berperilaku terhadap dua atau lebih objek (Kardes 2002).

Preferensi memiliki sifat-sifat dasar diantaranya adalah preferensi tidak mengandung kontrakdisi atau seseorang yang menyatakan preferensinya terhadap suatu produk tidak saling bertentangan satu dengan yang lainnya. Dengan kata lain, preferensi itu bersifat transitif (transitivity of preferences). Transitif dari preferensi adalah jika seseorang mengatakan bahwa ia lebih diinginkan A daripada B dan B lebih diinginkan daripada $\mathrm{C}$, maka $\mathrm{A}$ harus lebih diinginkan daripada $\mathrm{C}$. 
Selanjutnya, preferensi
adalah lengkap (complete plete preferences) yang berarti bahwa seseorang mampu menyatakan apa yang diinginkannya dari dua pilihan yang tersedia. Seseorang juga harus memiliki sikap yang konsisten dan masuk akal dalam mengekspresikan preferensinya terhadap suatu produk. Hal tersebut juga berarti bahwa jika A dan B merupakan dua kondisi, maka setiap orang harus selalu dapat menentukan pilihannya dengan tegas bahwa apakah A lebih disukai daripada B, B lebih disukai daripada A, atau A dan B sama-sama disukai.

Selain itu juga, seseorang lebih menyukai banyak barang daripada lebih sedikit barang. Hal tersebut terkait dengan prinsip "barang ekonomi" sebagai jenis barang yang menghasilkan manfaat positif bagi seseorang, maka lebih banyak barang yang disukainya maka akan lebih baik (Nicholson 2002).

Preferensi konsumen dapat didefenisikan sebagai pilihan suka atau tidak suka oleh seseorang terhadap suatu produk barang atau jasa yang dikonsumsi. Menurut Kotler (2001), preferensi konsumen menunjukkan kesukaan konsumen dari berbagai produk yang ada. Teori preferensi ini digunakan untuk menganalisis tingkat kepuasan bagi konsumen. Preferensi konsumen ini juga erat hubungannya dengan penetapan pilihan dan hubungan preferensi ini biasanya diasumsikan memiliki tiga sifat dasar yaitu:

1. Kelengkapan

Jika A dab B merupakn dua kondisi maka setiap orang selalu harus bisa menspesifikasikan apakah: a. A lebih disukai daripada $B$

b. B lebih disukai daripada $A$

c. A dan B sama-sama disukai

2. Transivitas (Transivity)

Jika seseorang mengatakan bahwa ia lebih menyukai A daripada B, dan lebih menyukai $\mathrm{B}$ daripada $\mathrm{C}$ maka ia harus lebih menyukai $\mathrm{A}$ daripada $\mathrm{C}$.

3. Kontinuitas (Continuity)

Jika seseorang mengatakan A lebih disukai daripada B maka situasi yang mirip dengan A harus disukai daripada B. Ketiga proposisi di atas diasumsikan tiap orang dapat membuat atau menyusun rangking semua kondisi atau situasi mulai dari yang paling disukai hingga yang paling tidak disukai (Nicholson 1999, diacu dalam Januarti 2005). Penilaian terhadap produk menggambarkan sikap konsumen terhadap produk tersebut dan sekaligus dapat mencerminkan perilaku konsumen dalam membelanjakan dan mengkonsumsi suatu produk

Menurut Kamus Besar

Bahasa Indonesia preferensi dapat diartikan sebagai (hak untuk) didahulukan daripada yang lain atau bisa juga diartikan sebagai pilihan, kecenderungan, kesukaan. Sehingga preferebsu dapat diartikan sebagai kecenderungan memilih atau preferensi ini bisa dipengaruhi oleh beberapa macam seperti faktor-faktor budaya, sosial, kepribadian dan psikologis.

\section{Preferensi Konsumen}

Preferensi konsumen adalah nilai-nilai bagi konsumen yang diperhatikan dalam menentukan sebuah pilihan. Dalam preferensi, konsumen akan menggunakan harapannya sebagai 
standar atau acuan. Harapan konsumen menjadi latar belakang mengapa dua organisasi pada bisnis yang sama dapat dinilai berbeda oleh pelanggannya.

Dalam konteks preferensi konsumen, umumnya harapan menjadi perkiraan atau keyakinan pelanggan tentang apa yang akan diterimanya nanti, dari definisi tersebut dapat disimpulkan bahwa pada dasarnya preferensi konsumen mencakup penilaian atau keinginan terbaik dari konsumen. Preferensi konsumen menentukan pilihan konsumen bila diharapkan pada banyak ragam pilihan produk yang sejenis.

Menurut Sudibyo (2002) preferensi konsumen merupakan nilainilai yang dianut konsumen dalam menghadapi berbagai bentuk konflik yang terjadi dalam lingkungannya. Konflik ini tidak harus dalam bentuk fisik tetapi pengertian konflik dimaksud meliputi konflik dalam arti perbedaan antara harapan dengan realisasi yang dirasakan dari permasalahan yang dihadapi. Dalam hal ini preferensi konsumen dianggap sebagai pandangan ideal atas keberadaan sebuah produk dilihat dari perspektif keinginan dan tuntutan konsumen. Preferensi konsumen mampu membentuk perilaku yang mengarah kepada sikap atau respon terhadap suatu produk.

\section{Pentingnya Pengukuran Preferensi Konsumen}

Agar pelanggan tidak meninggalkan perusahaan dan menjadi pelanggan pesaing, maka sebuah produk harus mengetahui preferensi konsumen sehingga setiap bentuk kebijakan yang ditetapkan sesuai dengan tuntutan dan keinginan konsumen. Dalam pengukuran preferensi konsumen, data yang diperoleh bersifat subjektif, sesuai dengan jawaban responden menurut pengalaman dalam menggunakan suatu jenis produk tertentu.
Menurut Sudibyo (2002) faktorfaktor yang menentukan preferensi konsumen dibedakan menjadi dua, yaitu:

1. Preferensi konsumen yang bersifat ekonomis

Preferensi konsumen yang bersifat ekonomis meliputi nilai dari pengorbanan dan manfaat yang diperoleh.

2. Preferensi konsumen yang bersifat non ekonomis

Preferensi konsumen yang bersifat non ekonomis yaitu kebutuhan aktualisasi diri dan penghargaan dari lingkungan.

Pentingnya pengukuran

terhadap preferensi konsumen adalah karena :

1. Sebagai dasar untuk menarik minat membeli konsumen pada suatu produk

2. Sebagai acuan bagi perusahaan untuk menerapkan programprogram pembangunan loyalitas konsumen

3. Untuk menjaga interaksi yang terus berkelanjutan antara konsumen dan perusahaan.

\section{Bank Syariah}

Kata bank berasal dari bahasa Italia yaitu "banco" yang berarti meja. Istilah ini didapat dikarenakan orang yang mengerjakan pekerjaan perbankan ini pada dasarnya menjadikan meja sebagai tempat untuk melayani orang-orang yang berhubungan dengan mereka. Kemudian berdasarkan pengembangannya, bank didefinisikan sebagai lembaga keuangan atau perusahaan yang bergerak di bidang keuangan (Khoiri, 2004).

Bank Islam adalah sebuah lembaga keuangan yang menjalankan operasinya menurut Hukum Islam untuk menghindarkan praktik bunga 
(riba/rente) sebab bunga dilarang dalam praktik Hukum Islam. Bank Islam sebagai lembaga keuangan dengan usaha pokoknya memberikan kredit dan jasa-jasa lainnya, di mana pelaksanaannya akan disesuaikan dengan prinsip-prinsip syariah Islam.

Pasal 1 angka (1) UndangUndang No. 21 Tahun 2008 tentang Perbankan Syariah menyatakan bahwa : "Perbankan syariah adalah segala sesuatu yang menyangkut tentang Bank Syariah dan unit usaha syariah, mencakup kelembagaan, kegiatan usaha serta cara dan proses dalam melaksanakan kegiatan usahanya".

Lebih lanjut lagi, Bank
Syariah adalah bank yang
menjalankan kegiatan usahanya berdasarkan prinsip syariah dan menurut jenisnya terdiri atas bank umum syariah dan bank pembiayaan rakyat syariah. Bank Umum Syariah adalah bank syariah yang dalam kegiatannya memberikan jasa dalam lalu lintas pembayaran. Bank Pembiayaan Rakyat Syariah adalah bank syariah yang dalam kegiatannya tidak memberikan jasa dalam lalu lintas pembayaran (Pasal 1 angka 7 Undang-Undang No. 21 Tahun 2008).

Bank Syariah juga dikenal dengan Bank Islam. Bank Syariah terdiri dari dua kata, yakni : Bank dan Syariah. Kata bank bermakna suatu lembaga keuangan yang berfungsi sebagai perantara keuangan dari pihak yang ingin menyimpan uangnya dan pihak pemilik perusahaan yang meminjamkan tempat untuk menyimpan uang. Kata syariah dalam menurut Bank Indonesia adalah aturan perjanjian berdasarkan kegiatan pihak penabung dan pihak penyewa tempat menabung untuk menyimpan dana dan / atau membiayai suatu kegiatan usaha yang sesuai dengan prinsip Hukum Islam (Ali, 2008).

Penggabungan kedua kata itu menjadikan kata Bank Syariah menjadi suatu lembaga keuangan yang berfungsi sebagai perantara bagi pihak yang kelebihan dana dengan pihak yang kekurangan dana untuk melaksanakan kegiatan usaha dan kegiatan lainnya sesuai dengan prinsip Hukum Islam yang mengharamkan bunga bank. Selain itu, Bank Syariah dalam kegiatan internasionalnya juga dikenal dengan istilah "Islamic Banking" yang biasanya disingkat dengan IB, yaitu suatu sistem perbankan dalam pelaksanaan operasional yang tidak menggunakan sistem bunga (riba), spekulasi (maisir) dan ketidakpastian (gharar). Beberapa praktisi ekonomi Islam memberikan definisi mengenai Bank Syariah sebagai berikut :

1. Abdul Wahab Khallaf menyatakan Bank Syariah adalah bank dalam beroperasinya dilakukan dengan cara bermuamalat secara Islami, mengacu kepada aturan yang ditegaskan oleh Al'Quran dan Hadist.

2. M. Amin Aziz menyatakan bahwa Bank Syariah merupakan lembaga perbankan yang menggunakan sistem dan operasinya dilaksanakan secara Syariah Islam, yang tata cara berusaha maupun perjanjiannya berusaha berdasarkan kepada Al'Quran 
dan Sunnah Rasul yang lebih menekankan kepada operasinya melalui sistem bagi hasil dan imbalan lainnya sesuai dengan syariah Islam dan menghindarkan riba yang dilarang oleh Syariah Islam (Rukmana, 2001).

3. Rachmadi Usman menyatakan bahwa Bank Syariah merupakan badan usaha yang kegiatan utamanya menghimpun dana dari masyarakat dan setelah terkumpul dana tersebut akan disalurkan kembali kepada masyarakat. Dalam kegiatan ini harus berdasarkan kepada mekanisme yang diatur menurut syariah berdasarkan kepada Al'Quran dan Hadist (Usman, 2001)

Kesimpulannya bank syariah merupakan lembaga keuangan yang sistem operasionalnya menghimpun dana dari masyarakat dan menyelaurkannya kembali dengan menggunakan sistem bagi hasil yang sesuai dengan prinsip syariah Islam yang telah diatur dalam Al'Quran dan Hadist. Lembaga dan instrumen keuangan Islam tidak cukup sekedar mengandalkan fanatisme emosional umat Muslim belaka, tetapi harus ditunjukkan dengan kinerja kerja yang profesional dan memberikan manfaat bagi seluruhnya.

\section{Syarat-syarat Pendirian Bank Syariah}

Setiap bank yang akan melakukan kegiatan usaha bank syariah atau unit usaha syariah wajib terlebih dahulu memperoleh izin usaha sebagai Bank Syariah atau
Unit Usaha Syariah (USS) dari Bank Indonesia. Untuk memperoleh izin usaha bank syariah harus memenuhi persyaratan sekurang-kurangnya tentang :

1. Susunan organisasi dan kepengurusan.

2. Permodalan.

3. Kepemilikan.

4. Keahlian di bidang Perbankan Syariah.

5. Kelayakan usaha.

6. Bank syariah yang telah memperoleh izin usaha wajib mencantumkan dengan jelas kata syariah pada penulisan nama banknya. Bank Umum Syariah hanya dapat didirikan dan / atau dimiliki oleh :

1. Warganegara Indonesia dan / atau badan hukum Indonesia.

2. Warganegara Indonesia dan / atau badan hukum Indonesia dengan warganegara asing dan / atau badan hukum asing secara kemitraan.

3. Pemerintah daerah.

Bank Pembiayaan Rakyat Syariah hanya dapat didirikan dan / atau dimiliki oleh :

1. Warganegara Indonesia dan / atau badan hukum Indonesia yang seluruh pemiliknya warganegara Indonesia.

2. Pemerintah daerah.

Menurut Peraturan Bank Indonesia No. 11/3/PBI/2009 tentang Bank Umum Syariah, modal untuk pendirian bank syariah sekurangkurangnya sebesar Rp 1.000.000.000.000,00 (satu trilyun rupiah). Sedangkan modal disetor untuk mendirikan Bank Perkreditan Rakyat Syariah (BPRS) menurut Peraturan Bank Indonesia No. 11/23/PBI/2009 tentang Bank 
Pembiayaan Rakyat Syariah ditetapkan sekurang-kurangnya:

1. Rp 2.000.000.000,00 (dua milyar rupiah) untuk BPRS uang didirikan di wilayah daerah Khusus Ibukota Jakarta Raya dan Kabupaten / Kota Tangerang, Bogor, Depok, Bekasi.

2. $\mathrm{Rp} 1.000 .000 .000,00$ (satu milyar rupiah) untuk BPRS yang didirikan di wialayah ibukota propinsi di luar wilayah tersebut pada huruf a di atas.

3. $\mathrm{Rp} 500.000 .000,00$ (lima ratus juta rupiah) untuk BPRS yang didirikan di luar wilayah pada huruf $a$ dan $b$ di atas.

Menurut Pasal 6 PBI No. 11/3/PBI/2009, bank hanya dapat didirikan oleh warganegara Indonesia dan / atau badan hukum Indonesia, atau warganegara Indonesia dan / atau badan hukum Indonesia dengan warganegara asing dan / atau badan hukum asing secara kemitraan atau pemerintah daerah. Kepemilikan yang berasal dari warganegara asing dan / atau badan hukum asing tersebut setinggitingginya sebesar $99 \%$ (sembilan puluh sembilan persen) dari modal yang disetor bank. BPRS hanya dapat didirikan dan / atau dimiliki oleh warganegara Indonesia, badan hukum Indonesia yang seluruh pemiliknya WNI, pemerintah daerah atau dua pihak atau lebih dari pihakpihak di atas.

Permohonan untuk mendapatkan persetujuan prinsip pada Bank Umum Syariah harus disertai dengan dokumen sebagai berikut :
1. Akta pendirian atau rancangan akta pendirian badan hukum Perseroan Terbatas (PT), termasuk anggaran dasar atau rancangan anggaran dasar.

2. Daftar pemegang saham.

3. Daftar calon anggota Dewan Komisaris, anggota Direksi dan anggota DPS.

4. Rencana susunan dan struktur organisasi serta nama-nama calon pejabat sampai dengan tingkat Pejabat Eksekutif.

5. Studi kelayakan mengenai peluang besar dan potensi ekonomi.

6. Rencana bisnis (business plan).

7. Rencana korporasi (corporate plan) berupa rencana strategis jangka panjang dalam rangka mencapai tujuan bank.

8. Pedoman manajemen resiko termasuk pedoman risk control system, rencana sistem pengendalian intern, rencana sistem teknologi informasi yang digunakan dan pedoman mengenai pelaksanaan atta kelola perusahaan yang baik (good corporate governance).

9. Sistem dan prosedur kerja yanglengkap dan komperehensif yang digunakan dalam kegiatan operasional bank.

10. Bukti setoran modal paling kurang $30 \%$ (tiga puluh persen) dari modal yang disetor.

11. Surat pernyataan dari pemegang saham bahwa sumber dana yang digunakan 
dalam rangka kepemilikan bank :
a. Tidak berasal dari pinjaman atau fasilitas pembiayaan dalam bentuk apapun dari bank dan / atau pihak lain.
b. Tidak berasal dari dan untuk tujuan pencucian uang (money laundering).

Persetujuan atau penolakan atas permohonan izin usaha diberikan selambat-lambatnya 60 (enam puluh) hari setelah dokumen permohonan diterima secara lengkap. Dalam rangka memberikan persetujuan atau penolakan, Bank Indonesia melakukan :

1. Penelitian atas kelengkapan dan kebenaran dokumen

2. Uji kemampuan dan kepatutan (fit and proper test) dan wawancara terhadap pemegang saham pengendali, calon anggota dewan komisaris, calon anggota direksi dan calon anggota Dewan Pengawas Syariah dalam hal terdapat penggantian atas calon yang diajukan sebelumnya.

Bank yang telah mencapat izin usaha dari Gubernur Bank Indonesia wajib melakukan kegiatan usaha perbankan selambat-lambatnya 60 (enam puluh) hari terhitung sejak tanggal izin usaha diterbitkan. Pelaksanaan kegiatan usaha wajib dilaporkan oleh Presiden Direktur atau Direktur Utama Bank kepada Bank Indonesia selambat-lambatnya 10 (sepuluh) hari setelah tanggal kegiatan pelaksanaan kegiatan usaha.

Apabila setelah jangka waktu yang telah ditentukan bank belum melakukan kegiatan usaha, maka
Gubernur Bank Indonesia dapat membatalkan izin usaha yang telah diterbitkan. Bank yang telah mendapat izin usaha dari Gubernur Bank Indonesia wajib mencantumkan secara jelas kata "Syariah" sesudah kata "Bank" atau setelah nama bank pada penulisan namanya.

Bagi bank konvensional yang ingin mengubah kegiatan usahanya menjadi bank berdasarkan prinsip syariah harus memenuhi ketentuan yang terdapat pada Peraturan Bank Indonesia No. 11/15/PBI/2009 tentang Perubahan Kegiatan Usaha Bank Konvensional menjadi Syariah. Perubahan kegiatan usaha bank konvensional menjadi bank syariah harus dengan izin dari Bank Indonesia dalam bentuk izin perubahan kegiatan usaha. Perubahan kegiatan usaha tersebut dapat dilakukan Bank Umum Konvensional menjadi Bank Umum Syariah dan Bank Prekreditan Rakyat menjadi Bank Perkreditan Rakyat Syariah. Bank konvensional yang akan melakukan perubahan kegiatan usaha menjadi bank syariah harus:

1. Menyesuaikan anggaran dasar.

2. Memenuhi persyaratan permodalan.

3. Menyesuaikan persyaratan direksi dan dewan komisaris.

4. Membentuk DPS.

5. Menyajikan laporan keuangan awal sebagai sebuah bank syariah.

6. Jenis-jenis Usaha Perbankan Syariah

Bank syariah terdiri dari Bank Umum Syariah dan Bank 
Pembiayaan Syariah, secara rinci kegiatan usaha yang dapat dilakukan oleh Bank Umum Syariah, antara lain :

1. Menghimpun dana dalam bentuk simpanan berupa giro, tabungan atau bentuk lainnya yang dipersamakan dengan itu berdasarkan Akad Wadi'ah atau akad lain yang tidak bertentangan dengan prinsip syariah.

2. Menghimpun dana dalam bentuk investasi berupa deposito, tabungan atau bentuk lainnya yang dipersamakan dengan itu berdasarkan Akad Mudharabah atau akad lain yang tidak bertentangan dengan prinsip syariah.

3. Menyalurkan pembiayaan bagi hasil berdasarkan Akad Mudharabah, Akad Musyarakah atau akad lain yang tidak bertentangan dengan prinsip syariah.

4. Menyalurkan pembiayaan berdasarkan Akad Murabahah, Akad Salam, Akad Istishna atau akad lain yang tidak bertentangan dengan prinsip syariah.

5. Menyalurkan pembiayaan berdasarkan Akad Qardh atau akad lain yang tidak bertentangan dengan prinsip syariah.

6. Menyalurkan pembiayaan penyewaan barang bergerak atau tidak bergerak kepada nasabah berdasarkan Akad Ijarah dan / atau sewa beli dalam bentuk ijarah muntahiya bittamlik atau akad lain yang tidak bertentangan dengan prinsip syariah.

7. Melakukan pengambilalihan utang berdasarkan Akad Hawalah atau Akad lain yang tidak bertentangan dengan prinsip syariah.

8. Melakukan usaha kartu debit dan / atau kartu pembiayaan berdasarkan prinsip syariah.

9. Membeli, menjual atau menjamin atas resiko sendiri surat berharga pihak ketiga yang diterbitkan atas dasar transaksi nyata berdasarkan prinsip syariah, antara lain: Akad Ijarah, Musyarakah, Mudharabah, Murabahah, Kafalah atau Hawalah.

10. Membeli surat berharga berdasarkan prinsip syariah yang diterbitkan oleh pemerintah dan / atau Bank Indonesia.

11. Menerima pembayaran dari tagihan atas surat berharga dan melakukan perhitungan dengan pihak ketiga atau antar pihak ketiga berdasarkan prinsip syariah.

12. Melakukan penitipan untuk kepentingan pihak lain berdasarkan suatu akad yang berdasarkan prinsip syariah.

13. Menyediakan tempat untuk menyimpan barang dan surat berharga berdasarkan prinsip syariah.

14. Memindahkan uang, baik untuk kepentingan sendiri maupun untuk kepentingan nasabah berdasarkan prinsip syariah.

15. Melakukan fungsi sebagai wali amanat berdasarkan Akad Wakalah. 
16. Memberikan fasilitas letter of credit atau bank garansi berdasarkan prinsip syariah.

17. Melakukan kegiatan usaha yang lazim dilakukan di bidang perbankan dan di bidang sosial sepanjang tidak bertentangan dengan prinsip syariah dan sesuai dengan ketentuan peraturan perundang-undangan.

Selain itu, Bank Umum Syariah dapat pula melakukan beberapa jenis kegiatan usaha sebagai berikut :

1. Melakukan kegiatan valuta asing berdasarkan prinsip syariah.

2. Melakukan kegiatan penyertaan modal pada Bank Umum Syariah atau lembaga keuangan yang melakukan kegiatan usaha berdasarkan prinsip syariah.

3. Melakukan kegiatan penyertaan modal sementara untuk mengatasi akibat kegagalan pembiayaan berdasarkan prinsip syariah dengan syarat harus menarik kembali penyertaannya.

4. Bertindak sebagai pendiri atau pengurus dana pensiun berdasarkan prinsip syariah.

5. Melakukan kegiatan dalam pasar modal sepanjang tidak bertentangan dengan prinsip syariah dan ketentuan peraturan perundangundangan di bidang pasar modal.

6. Menyelenggarakan kegiatan atau produk bank yang berdasarkan prinsip syariah dengan menggunakan sarana elektronik.

7. Menerbitkan, menawarkan dan memperdagangkan surat berharga jangka pendek berdasarkan prinsip syariah, baik secara langsung maupun tidak langsung melalui pasar modal.

8. Menerbitkan, menawarkan dan memperdagangkan surat berharga jangka panjang berdasarkan prinsip syariah, baik secara langsung maupun tidak langsung melalui pasar modal.

Menyediakan produk atau melakukan kegiatan usaha Bank Umum Syariah lainnya yang berdasarkan prinsip syariah.

\section{Metode Penelitian}

1. Teknik Pengumpulan Data

Adapun teknik pengumpulan data yang digunakan dalam penelitian ini adalah:

a. Observasi

Digunakan untuk mengamati gejala-gejala terwujud dalam kehidupan sehari-hari dari masyarakat yang diteliti. Metode ini memberi gejalagejala (tindakan- tindakan, benda, peristiwa dan sebagainya) dan kaitan hubungan antara satu gejala dengan gejala yang lainnya yang bermakna bagi kehidupan masyarakat yang diteliti. Metode observasi atau pengamatan dilaksanakan dengan cara berusaha mengamati secara langsung tentang preferensi masyarakat pesantren terhadap bank 
syariah dan pengamatan ini diketahui oleh mereka dan mereka secara sukarela memberikan kesempatan kepada pengamat untuk melakukan pengamatan tersebut guna memperoleh data-data yang di perlukan dalam penelitian.

b. Wawancara

Yaitu teknik yang dapat digunakan untuk memperoleh data atau informasi secara langsung pada informan. Teknik ini bertujuan untuk mengumpulkan keterangan tentang kehidupan manusia dalam masyarakat serta pendirian-pendirian mereka dalam hal-hal tertentu. Wawancara yang dilakukan bersifat mendalam, untuk mengetahui apa yang terkandung dalam pikiran dan hati orang lain yang meliputi motivasi, perasaan, pandangan, harapan dan pengalaman hidup yang tidak dapat diketahui melalui pengamatan saja.

Wawancara mendalam ini dilakukan secara tatap muka (face to face) sebagai sebuah dialog atau percakapan yang spontan. Sebelumnya yang akan penulis lakukan adalah berkenalan dan membina hubungan baik dengan beberapa masyarakat pesantren yang ada di Pekanbaru.

c. Interview guide

Yaitu catatan yang mengandung daftar dari pokokpokok untuk dipertanyakan kepada informan atau yang disebut dengan pedoman wawancara. Penulis dalam hal ini telah menyiapkan daftar pokok-pokok pertanyaan yang akan ditanyakan kepada para informan meliputi segala hal yang berhubungan dengan preferensi masyarakat pesantren terhadap bank syariah. Hal ini digunakan untuk memperoleh data-data yang akan digunakan dalam melakukan penelitian ini.

d. Kuesioner

Adalah teknik pengumpulan data dengan mengajukan sejumlah pertanyaan secara tertulis yang diberikan kepada responden dengan maksud untuk memperoleh data yang akurat dan valid.

\section{Populasi dan Sampel}

Populasi adalah jumlah keseluruhan dari unit analisa yang ciri-cirinya akan diduga (Singarimbun dan Effendi, 1984). Populasi informan adalah para masyarakat pesantren di Kecamatan Tampan yang menjadi nasabah bank syariah. Masyarakat pesantren yang diambil sebagai sarana penelitian dipilih secara acak dengan indikasi masyarakat pesantren tersebut merupakan nasabah bank syariah di Kecamatan Tampan.

\section{Jenis dan Sumber Data}

a. Data primer

Adalah data yang diperoleh melalui penelitian langsung terhadap objek yang diteliti.

b. Data sekunder

Adalah data yang diperoleh dari berbagai sumber antara lain dari dokumentasi tulisan dan dari 
informasi pihak-pihak yang berkaitan dengan penelitian ini.

\section{Teknik Analisis Data}

Analisa data dilakukan secara kualitatif dan kuantitatif sesuai dengan metode yang dilakukan dalam penelitian ini. Analisa data kualitatif adalah mengalokasikan data, memilah-milahnya menjadi satuan yang dapat dikelola, mensintesiskannya, mencari dan menemukan pola, menemukan apa yang penting dan apa yang dipelajari, dan memutuskan apa yang dapat diceritakan kepada orang lain.

Sedangkan analisa data kuantitatif menggunakan model regresi linier berganda (multiple linier regretion) dalam (Ghozali, 2005) dengan formulasi sebagai berikut : $Y=\alpha+\beta_{1} X_{1}+\beta_{2} X_{2}+$ $\beta_{3} X_{3}+\mathbf{e}$

$\mathrm{Y}=$ Preferensi masyarakat pesantren

$\mathrm{X}_{1}=$ Manfaat yang diperoleh

$\mathrm{X}_{2}=$ Aktualisasi diri

$\mathrm{X}_{3}=$ Penghargaan dari lingkungan

$\alpha=$ Konstanta

$\beta_{1}, \beta_{2}, \beta_{3}=$ Koefisien regresi

$\mathrm{e}=$ Variabel pengganggu

Hasil persamaan regresi tersebut kemudian dianalisis dengan menggunakan beberapa metode pengujian hipótesis sebagai berikut :

1. Uji Pendahuluan

Pada suatu penelitian alat ukur ysng digunakan untuk mengumpulkan data harus sahih dan andal. Kesahihan (Validitas) dan Keandalan (realibitas) suatu hasil penelitian tergantung kepada alat ukur (instrument) yang digunakan dan data yang diperoleh. a. Uji Validitas

Menurut Imam

Ghazali (2005: 45) Uji validitas data digunakan untuk mengukur sah atau valid tidaknya suatu kuesioner. Validitas data dapat ditafsirkan berdasarkan faktor tertentu dan koefisien phi (korelasi antar faktor). Faktor Gamma (faktor loading) menggambarkan seberapa kuat butir-butir instrumen (variabel terukur) menyatu satu sama lainnya. Jika semua koefisien Gamma cukup tinggi, maka dapat ditafsirkan butir-butir tersebut koheren. Artinya berfungsi dari satu konsep yang sama. Dengan kata lain secara empirik mempunyai validitas yang baik. Korelasi antar faktor (phi) menunjukkan berapa erat masing-masing faktor sebagai dimensi. Sebagai variabel yang lebih besar mempunyai hubungan satu dengan lainnya (memililki faktor loading >0,5).

Pernyataan dikatakan valid jika nilai $r$ hitung lebih besar dari $r_{\text {tabel }}$ korelasi pada derajat bebas $(d b) n-2$ atau jika probabilitas $<0,05$.

b. Uji Reliabilitas

Menurut Imam

Ghazali (2005: 41) Uji reliabilitas ditujukan untuk menguji sejauh mana suatu hasil pengukuran relatif konsisten apabila pengukuran diulangi dua kali atau lebih. Jadi reliabilitas adalah indeks 
yang menunjukkan sejauh mana suatu alat ukur dapat dipercaya atau diandalkan bila alat ukur tersebut digunakan dua kali untuk mengukur gejala yang sama, maka hasil pengukuran yang diperoleh relatif konsisten.

Pengujuian dilakukan dengan menggunakan teknik cronbach alpa. Dimana suatu instrumen dapat dikatakan reliabel bila memiliki koefisien keandalan atau alpha sebesar: (a) 0,6 tidak reliabel, (b) $\quad 0,6-0,7$ acceptable, (c) 0,7-0,8 baik dan (d) 0,8 sangat baik.

2. Uji Asumsi Klasik

a. Uji Normalitas

Imam Ghazali (2005: 110) Uji normalitas bertujuan untuk menguji apakan dalam model regresi, variabel pengganggu (residual) memiliki distribusi normal, seperti diketahui, uji t dan uji F mangasumsikan bahwa nilai residual mengikuti distribusi normal.

Deteksi normalitas dilakukan dengan melihat penyebaran data (titik) pada sumbu diagonal dari grafik. Jika data menyebar di sekitar garis diagonal, maka model regresi memenuhi asumsi Normalitas.

b. Uji Autokorelasi

Imam Gazali (2005)

Uji autokorelasi bertujuan menguji apakah dalam model regresi linear ada korelasi antara kesalahan pengganggu pada periode $t$ dengan kesalahan pengganggu pada periode $\mathrm{t}-1$ (sebelumnya). Jika terjadi korelasi, maka dinamakan ada problem autokorelasi. Autokorelasi muncul karena observasi yang berurutan sepanjang waktu berkaitan satu sama lainnya. Masalah ini timbul karena residual (kesalahan pengganggu) tidak bebas dari satu observasi ke observasi lainnya. Model regresi yang baik adalah regresi yang bebas dari autokorelasi.

Pengujian ini

dilakukan Durbin-Watson (Tabel DW Test), dasar pengambilan keputusannya adalah:

1. Angka D-W dibawah -2 berarti ada autokorelasi

2. Angka DW diantara -2 sampai 2 berarti tidak ada autokorelasi

3. Angka DW diatas 2 berarti ada autokorelasi

c. Uji Heterokedisitas Imam Ghazali (2005) Uji heteroskedastisitas bertujuan menguji apakah model regresi terjadi ketidaksamaan variance dari residual satu pengamatan ke pengamatan lainnya. Jadi Heterokedisitas ini akan terjadi apabila varian e (gangguan/disturbance) tidak mempunyai penyebaran yang sama, sehingga model yang sudah dibuat menjadi kurang efisien.

3. Uji Parsial (Uji t) 
Untuk mengetahui pengaruh antara variabel dependen dan independen secara parsial akan diketahui bagaimana pengaruh variable tersebut. Analisis ini menggunakan tingkat kepercayaan dan derajat kebebasan untuk dapat menentukan nilai kritis. Pengujian dengan membandingkan nilai thitung dan nilai table atau melihat $\mathrm{P}$ Value masing-masing sehingga bias ditentukan apakah hipotesa yang telah dibuat signifikan. Hipotesa menggunakan statistic satu sisi (one tails). Criteria diterima atau ditolaknya hipotesis adalah sebagai berikut :

1. Terdapat pengaruh secara parsial dari variable independen terhadap dependen jika $t$ hitung $>\mathrm{t}$ table atau $P$ value $<\alpha$

2. Tidak terdapat pengaruh secara parsial dari variable indepen terhadap variable dependen jika $\mathrm{t}$ hitung $<\mathrm{t}$ table atau $\mathrm{P}$ value $>\alpha$

\section{Uji F}

Jika $\mathrm{F}_{\text {hituing }}>\mathrm{F}$ table ,maka hipotesis 1 diterima. Artinya variabel $\mathrm{X}_{1}$ dan $\mathrm{X}_{2}$ secara bersama-sama berpengaruh secara signifikan terhadap variabel $\mathrm{Y}$. Jika $\mathrm{F}$ hituing $<\mathrm{F}$ table, maka hipotesis 1 ditolak. Artinya variabel $\mathrm{X}_{1}$ dan $\mathrm{X}_{2}$ secara bersama-sama tidak berpengaruh secara signifikan terhadap variabel Y.

\section{HASIL DAN PEMBAHASAN}

a. Uji Normalitas
Uji normalitas bertujuan untuk mengetahui apakah distribusi sebuah data mengikuti atau mendekati distribusi normal. Data yang baik adalah yang mempunyai pola seperti distribusi normal (Tidak melenceng ke kiri dan ke kanan). Dari hasil pengolahan data dengan metode SPSS dapat dikemukakan bahwa nilai-nilai sebaran data terletak di sekitar garis lurus, sehingga persyaratan normalitas dapat dipenuhi.

\section{b. Uji Multikolinearitas}

Untuk menguji apakah tidak adanya multikolinearitas antara sesama variabel bebas yang ada dalam model atau dapat dikatakan tidak adanya hubungan linear yang sempurna antara variabel bebas yang ada dalam model maka dapat dilihat dari nilai VIF (Variance Inflation Factor) sebagai berikut :

$\begin{array}{lll}\text { - } \quad \text { VIF untuk } X_{1} & =1,069 \\ \text { - } \quad \text { VIF untuk } X_{2} & =1,055 \\ \text { - } & \text { VIF untuk } X_{3} & =1,014\end{array}$

Berdasarkan hasil

perhitungan tersebut diatas terlihat bahwa nilai VIF yang ada tidak lebih besar dari 10 sehingga tidak ada multikolinearitas pada model yang dibuat.

c. Pembuktian Hipotesis Secara Total

Pembuktian hipotesis secara total digunakan untuk melihat pengaruh variabel bebas secara bersama-sama terhadap variabel terikatnya dalam hal ini adalah preferensi masyarakat pesanten. Berdasarkan hasil perhitungan melalui komputer dengan menggunakan program SPSS, maka 
diperoleh data-data perhitungan sebagai berikut :

\section{Koefisien Regresi Tentang} Preferensi Masyarakat Pesantren Terhadap Bank Syariah

\begin{tabular}{|c|c|c|c|c|}
\hline $\begin{array}{c}\text { Variabe } \\
\text { l }\end{array}$ & $\begin{array}{c}\text { Koef. } \\
\text { Regresi }\end{array}$ & Error & $\mathbf{t}$ & Sig \\
\hline Constan & 1,352 & 0,308 & 4,383 & 0,000 \\
t & 0,406 & 0,052 & 7,859 & 0,000 \\
$\mathrm{X}_{1}$ & 0,203 & 0,045 & 4,464 & 0,000 \\
$\mathrm{X}_{2}$ & 0,168 & 0,046 & 3,641 & 0,000 \\
$\mathrm{X}_{3}$ & \multicolumn{5}{|l}{} \\
R Squared $=0,566$ & \\
F Ratio $=41,808$ \\
Sig.
\end{tabular}

Sumber : Data Olahan

Berdasarkan tabel diatas di peroleh koefisien determinasi berganda ( $\mathrm{R}$ squared) yang diperoleh dari kelipatan (R) adalah sebesar 0,566 menunjukkan bahwa 56,6\% preferensi masyarakat pesantren $(\mathrm{Y})$ bisa diterangkan dengan variabel manfaat yang diperoleh $\left(\mathrm{X}_{1}\right)$, aktualisasi diri $\left(\mathrm{X}_{2}\right)$, penghargaan dari lingkungan $\left(\mathrm{X}_{3}\right)$ sedangkan sisanya $(100 \%-56,6 \%=43,4 \%)$ dapat diterangkan oleh variabel lain yang tidak diteliti pada penelitian ini.

Teknik analisis data regresi linier berganda (multiple regression analysis) bertujuan untuk mencari hubungan antara variabel bebas yaitu manfaat yang diperoleh $\left(\mathrm{X}_{1}\right)$, aktualisasi diri $\left(\mathrm{X}_{2}\right)$, penghargaan dari lingkungan $\left(\mathrm{X}_{3}\right)$ terhadap variabel terikat yaitu preferensi masyarakat pesantren. Berdasarkan kepada tabel diatas maka diperoleh model persamaan regresi linier berganda sebagai berikut :

$$
\mathrm{Y}=1,352+0,406 \mathrm{X}_{1}+0,203 \mathrm{X}_{2}+
$$

Persamaan

tersebut

menunjukkan bahwa koefisien regresi dari ketiga variabel bebas yaitu $b_{1}, b_{2}, b_{3}$ bertanda positif (+).
Dimana hal ini berarti apabila variabel manfaat yang diperoleh $\left(b_{1}\right)$, aktualisasi diri $\left(b_{2}\right)$, penghargaan dari lingkungan $\left(b_{3}\right)$ ditingkatkan perannya maka akan menimbulkan peningkatan pula pada variabel terikatnya.

Selanjutnya untuk membuktikan secara keseluruhan apakah semua variabel bebas secara bersama-sama mempunyai pengaruh terhadap variabel terikat maka digunakan uji-F, dengan ketentuan :

- Jika F hitung > F tabel maka terdapat hubungan/pengaruh antara variabel bebas dengan variabel terikatnya.

- Jika F hitung < F tabel maka tidak terdapat pengaruh atau dengan kata lain variabel bebas tidak dapat menerangkan variabel tidak bebasnya (Variabel terikat).

Dari tabel diatas diperoleh F hitung adalah sebesar 41,808 dan dengan tingkat signifikan sebesar 0,000 , sedangkan $\mathrm{F}$ tabel dengan tingkat signifikan $\alpha \square 0,05=2,70$. Jadi dapat disimpulkan bahwa $\mathrm{F}$ hitung lebih besar dari $\mathrm{F}$ tabel $(41,808>2,70)$.

Dengan demikian hipotesis yang didukung dengan variabel bebas dalam penelitian ini mempunyai pengaruh terhadap preferensi masyarakat pesantren.

\section{d. Pembuktian Hipotesis Secara Parsial \\ Untuk membuktikan} hipotesis secara parsial digunakan uji-t yaitu untuk mengetahui besarnya pengaruh masing-masing variabel bebas secara parsial atau sendiri-sendiri dalam menjelaskan variabel terikatnya sehingga diketahui variabel bebas mana yang 
paling dominan mempengaruhi variabel terikat yaitu preferensi masyarakat pesantren dari keseluruhan variabel babas yang diteliti dalam penelitian ini.

$$
\text { Berdasarkan hasil }
$$

perhitungan dengan menggunakan paket program SPSS diperoleh besarnya nilai koefisien regresi secara parsial dari masing-masing variabel bebas yang diteliti yaitu seperti yang terlihat pada tabel berikut:

\section{Koefisien Regresi Variabel Bebas Secara parsial Terhadap Variabel} Terikat

\begin{tabular}{|c|c|c|c|c|}
\hline Variabel & Beta & t-tabel & t-hitung & Sig. \\
\hline $\mathrm{X}_{1}$ & 0,406 & 1,660 & 7,859 & 0,000 \\
$\mathrm{X}_{2}$ & 0,203 & 1,660 & 4,464 & 0,000 \\
$\mathrm{X}_{3}$ & 0,168 & 1,660 & 3,641 & 0,000 \\
\hline
\end{tabular}

\section{Sumber : Data Olahan}

Dari tabel diatas maka dapat dibuktikan kebenaran hipotesis yang diajukan secara parsial, dengan ketentuan :

a. Apabila t-hitung $>\mathrm{t}$-tabel maka variabel bebas dapat menerangkan variabel tidak bebasnya atau dengan kata lain terdapat pengaruh diantara semua variabel yang diteliti.

b. Apabila t-hitung < t-tabel maka variabel bebas tidak dapat menerangkan variabel tidak bebasnya atau dengan kata lain tidak terdapat pengaruh diantara semua variabel yang diteliti.

Uji-t ini dilakukan dengan membandingkan t-hitung dengan ttabel pada signifikan $\alpha=0,05 \%$. Pada t-tabel diperoleh $\mathrm{t}$ nya adalah sebesar 1,660. Maka hasil pengujian dari masing-masing variabel bebas tersebut adalah :

a. Variabel $\mathrm{X}_{1}$ (manfaat yang diperoleh) $7,859>1,660$, maka dapat disimpulkan bahwa variabel $\mathrm{X}_{1} \quad$ berpengaruh terhadap preferensi masyarakat pesantren (dengan signifikan sebesar 0,000).

b. Variabel $\mathrm{X}_{2}$ (aktualisasi diri) 4,464 > 1,660, maka dapat disimpulkan bahwa variabel $\mathrm{X}_{2}$ berpengaruh terhadap preferensi masyarakat pesantren (dengan signifikan sebesar 0,000).

c. Variabel $\mathrm{X}_{3}$ (penghargaan dari lingkungan) 3,641 > 1,660, maka dapat disimpulkan bahwa variabel $\mathrm{X}_{3} \quad$ berpengaruh terhadap preferensi masyarakat pesantren (dengan signifikan sebesar 0,000).

Dari penjelasan diatas maka dapat disimpulkan bahwa ketiga variabel diatas yaitu variabel manfaat yang diperoleh $\left(\mathrm{X}_{1}\right)$, aktualisasi diri $\left(\mathrm{X}_{2}\right)$, penghargaan dari lingkungan $\left(\mathrm{X}_{3}\right)$ benar-benar berpengaruh terhadap preferensi masyarakat pesantren, karena t-hitung dari keseluruhan variabel tersebut lebih besar dari t-tabelnya.

Selanjutnya dari keseluruhan variabel bebas yang diteliti, variabel $\mathrm{X}_{1}$ (manfaat yang diperoleh) mempunyai pengaruh yang paling dominan dalam menerangkan variabel terikatnya yaitu preferensi masyarakat pesantren pada Bank Syariah di Kecamatan Tampan.

\section{PENUTUP}

Beberapa kesimpulan yang
dapat penulis kemukakan berdasarkan kepada hasil penelitian ini adalah faktor-faktor word of mouth marketing yang terdiri dari talkers $\left(\mathrm{X}_{1}\right)$, topics $\left(\mathrm{X}_{2}\right)$, tools $\left(\mathrm{X}_{3}\right)$, takings parts $\left(\mathrm{X}_{4}\right)$ dan traking $\left(\mathrm{X}_{5}\right)$ berpengaruh terhadap minat pengajuan kredit pada Bank Danamon Simpan Pinjam di Kota 
Pekanbaru. Faktor yang dominan mempengaruhi minat pengajuan kredit pada Bank Danamon Simpan Pinjam di Kota Pekanbaru adalah talkers.

\section{DAFTAR PUSTAKA}

Antonio, Syafii, 2003. Bank Syariah Bagi Bankir dan Praktisi Keuangan, Jakarta : Tazkia Institute.

Arikunto, Suharsimi, 2002. Prosedur Penelitian, Jakarta : Rineka Cipta

Bungin, Burhan, 2001. Metodologi Penelitian Sosial, Surabaya: Airlangga University Press.

Chapra, Umer, 2002. The Future of Economics an Islamic Perspective. Jakarta : Asy Syaamil Press \& Grafika.

Hamidi, M Luthfi, 2003. Jejak-jejak Ekonomi Syariah, Jakarta: Senayan Abadi Publishing.

Karim, Adiwarman, 2004. Bank Islam Analisis Fiqih dan Keuangan, Jakarta: Raja Grafindo Persada.
Kasmir, 2008. Bank dan Lembaga Keuangan Lainnya, Jakarta: Rajawali Pers.

Koentjaraningrat, 1981, MetodeMetode Penelitian

Masyarakat, Gramedia, Jakarta.

Kotler. P, 1987. Manajemen Pemasaran. PT.Prenhallindo, Jakarta.

Moleong, Lexy. J, 2005, Metodologi Penelitian Kualitatif, Remaja Rosdakarya, Bandung.

Sarwono, J. 2009. Statistik Itu Mudah. Yogyakarta: CV Andi Offset.

Santoso, S. 2002. Buku Latihan SPSS Statistik Multivariat. Jakarta: PT Elex Media Komputindo.

Sugiyono, 2005. Metode Penelitian Bisnis, Bandung, Alfabeta

Suprayitno, Eko, 2005. Ekonomi Islam Pendekatan Ekonomi Makro Islam dan Konvensional, Jakarta : Graha Ilmu. 